\title{
Applying boron to coconut palm plants: effects on the soil, on the plant nutritional status and on productivity boron to coconut palm trees
}

\author{
J. Z. Moura ${ }^{1}$, R.M. Prado ${ }^{2 *}$, R.N. Benvindo ${ }^{1}$ and L. Chaves Alencar ${ }^{1}$ \\ 1 Federal University of Piaui, Campus Professora Cinobelina Elvas, Rodovia BR 135, Km 03, 64900-000 - Bom Jesus,Pi, Brazil. \\ 2Department of Soils and Fertilizers, State University of Sao Paulo UNESP), Via de Acesso Paulo Donato Castallane, $s / n$. \\ 14884-900, Jaboticabal, Brazil.*Corresponding author: rmprado@fcav.unesp.br
}

\begin{abstract}
Boron, one of the micronutrients frequently found in low levels in tropical soils affects nutrition and productivity of coconut palm trees essentially cultivated in tropical climates. The objective of this research study was to evaluate the effect of boron on the nutritional status of the plant and its productivity when artificially applied to the culture soil. The experiment was carried out in a four year old, artificially irrigated, dwarf coconut palm orchard in Brazil, between January, 2005 and October, 2006. The soil was a red yellow Latosol (B: $0.18 \mathrm{mg} \mathrm{dm}^{-3}$ ). The treatments consisted in the application of five boron dosages: zero, $1,2,4$, and $6 \mathrm{~kg} \mathrm{ha}^{-1}$. In the field, the treatments were arranged according to a completely randomized block design, with four replications. Boron (borax) dosages were applied in equal halves directly into the soil in the months of January and February of 2005. Boron concentration in the soil and plant and plant productivity were evaluated. The higher palm tree production was associated to levels of $0.6 \mathrm{mg} \mathrm{dm}^{-3}$ of B in the soil and $23.5 \mathrm{mg} \mathrm{kg}^{-1}$ in leaves. Ninety five percent of palm trees maximum production was obtained with the use of a boron dosage of $2,1 \mathrm{~kg} \mathrm{ha}^{-1}$.
\end{abstract}

Keywords: Cocos nucifera L, mineral nutrition, micronutrients.

\section{Introduction}

Cultivation of coconut palm (Cocos nucifera L.) trees has grown steadily in recent years not only in Latin America but in several parts of the world. The species is mainly cultivated in lowland coastal areas usually characterized by low fertility soils, the main cause of low productivity. Notwithstanding its recognized economic importance, mineral nutrition of coconut palm plants has received little attention from investigators in the area. The poor available information refers essentially to the giant variety (cultivars of coconut that bear fruit at a later stage than the "dwarf" varieties) or to the hybrid genotype (Santos et al., 2004). The most important observations indicate that mineral nutrient deficiencies, mainly of micronutrients, cause reductions in the 
number of feminine flowers per spathe and the fruits, which eventually succeed easily drop off the plant, a condition generally referred to as "abortion of immature fruits" (Holanda et al, 2007; Siqueira et al., 1997). Nutritional equilibrium is essential for high and sustainable productivity of the coconut palm tree (Srinivasa Reddy et al., 2002).

Low levels of boron found in tropical soils is, according to Mattiello et al. (2009), attributable to factors such as naturally occurring low fertility levels, removal of nutrients by several successive crops, and the increased use of fertilizers and acidity correctives, which contribute to decrease the solubility of several soil minerals (Keren and Bingham, 1985). Silva et al. (1995) and Communar and Keren (2006) also point out the importance of factors such as sandy soils, low in organic matter and exposed to heavy rains, which drain much of the boron to deeper layers. In heavy, clayish soils, boron may also be unavailable to plants due to strong adsorption to soil particles (Chaudary and Shukla, 2004). Chronic B deficiencies, caused by soil drying and/or high soil $\mathrm{pH}$ affect multiple leaves and ultimately, productivity.

Boron deficiency, in general, reduces root growth (Lima Filho and Malavolta, 1997; Viegas et al., 2004) and in the coconut palm tree, production of total roots is reduced by $30 \%$ and of thin roots by $48 \%$ ( Pinho et al. 2008a), Sobral (1998), Broschat (2005), and Santos et al. (2003) observed that boron deficiency also damages the plant aerial part, which produces less expanded young leaves with signs of blighted, necrotic, and corky areas. The primary symptoms of $B$ deficiency in coconut trees are leaflet tip truncation, leaf crumpling or distortion, and failure of the spear leaf to open normally.

Santos et al. (2004), in an evaluation of the nutritional status of a coconut palm orchard, reported that boron was one of the most yield limiting factors. According to their findings, the most important elements for coconut production in decreasing importance were K > Ca > B. Sobral (1998), Rognon (1984), and
Manciot et al. (1980) observed that a critical boron level in plant leaves was $10 \mathrm{mg} \mathrm{kg}^{-1}$.

General recommendations for the application of boron to coconut plants are that young plants should receive $30 \mathrm{~g}$ of borax applied to the $4^{\text {th }}$ leaf axilla. For producing plants, it is recommended that the micronutrient should be applied directly into the soil - in a dosage of $2 \mathrm{~kg} \mathrm{ha}^{-1}$ of B as borax (Sobral, 1997) when analysis indicates levels lower than $0.2 \mathrm{mg} \mathrm{dm}^{-3}$ (hot water) (Teixeira et al. 2005). The application of boron directly into the soil is more efficient than foliar techniques due to the low mobility it shows in plant tissues. Boron applied to the soil has a more persistent effect than when it is deposited in leaf axillae (Pinho et al., 2008b; Broschat, 2011).

Recommendations about boron dosages to be applied to coconut plants are scarcely found in the literature (Teixeira and Silva, 2003; Santos et al., 2003). The objective of this research study was to evaluate the effects of boron applied to the soil by measuring concentrations of the nutrient in plant leaves and the production of fruit.

\section{Material and Methods}

This research project was carried out at the "Nossa Senhora Aparecida" farm, in Uberlandia, state of Minas Gerais, Brazil, between January of 2005 and October of 2006, in a producing orchard of coconut trees of the dwarf-green variety (cultivar Anão Verde do Brasil de Jequiti). The trees growing in a redyellow Latosol (162 $\mathrm{g} \mathrm{kg}^{-1}$ of clay) were artificially irrigated. The climate of the region, according to Koppen's classification, is described as Aw Megathermic, characterized by the occurrence of rains during summers (from October through March) and by a dry period during the winter (from May through September)( Rosa et al. 1991). 
Soil data, as shown by chemical analyses, were the following: 1- $\mathrm{pH}\left(\mathrm{CaCl}_{2}\right)$ : 5.2. 2- Organic matter: 19 $\mathrm{g} \mathrm{dm}^{-3}$. 3- $\mathrm{P}$ (by ionic resin exchange): $49 \mathrm{~g} \mathrm{dm}^{-3}$. 4- $\mathrm{K}: 1.0 \mathrm{mmol} \mathrm{dm}^{-3}$. 5- Ca: $32 \mathrm{mmolc} \mathrm{dm}{ }^{-3}$. 6- $\mathrm{Mg}$ : $13 \mathrm{mmol}_{\mathrm{c}} \mathrm{dm}^{-3}$. 7- $\mathrm{H}+\mathrm{Al}: 22 \mathrm{mmol}_{\mathrm{c}} \mathrm{dm}^{-3}$. 8.-CTC (Cation Exchange Capacity): $68.9 \mathrm{mmol}_{\mathrm{c}} \mathrm{dm}^{-3}$. 9V (Bases Saturation): $68 \%$. 10. B: $0.18 \mathrm{mg} \mathrm{dm}^{-3}$. This B value is low according to Raij et al. (1997), indicating that the soil in the experimental cultures should respond to boron fertilization.

The coconut palm orchard was annually fertilized with a mixture of $1.5 \mathrm{~kg}$ of N, $0.4 \mathrm{~kg}$ of $\mathrm{P}_{2} \mathrm{O}_{5}$, and 1.8 $\mathrm{kg}$ of $\mathrm{K}_{2} \mathrm{O}$ per plant, following recommendation by Sobral (1998). The mixture was applied over a 40 $\mathrm{cm}$ wide band at a distance of $30 \mathrm{~cm}$ from the plant trunk. Phosphorus was applied in a single dosage (January of 2005) whereas $\mathrm{N}$ and $\mathrm{K}$ applications were split in four - in January, February, March, and April of 2005.

Boron treatments described in this report consisted of five dosages: $0,1,2,4$, and $6 \mathrm{~kg}$ of $\mathrm{B}$ (as borax) per hectare applied in two equal parts each in a volume of $600 \mathrm{~L} \mathrm{ha}^{-1}$ and corresponding to concentrations of borax of $0,0.72,1.45,2.9$, and $4.35 \%$,respectively. The treatments were arranged in the experimental area according to a completely randomized block design, with four repetitions. In each of the two applications $3.4 \mathrm{~L}$ of the boron solution dose were sprayed $(3,4 \mathrm{~L}$ of solution per plant, in a circular area of $1,25 \mathrm{~m}^{2}$ of soil around each plant) one in January and the other in February of 2005, in order to reduce fertilizer losses from leaching.

In March of 2006, soil samples were taken from 12 points of the fertilized areas and then mixed so as to obtain a composite sample, which was used to represent boron concentration in the soil. The analytical procedure was that described by Raij et al. (2001).

Analysis of leaf samples harvested in April of 2006 was as described by Rognon (1984). The samples consisted of leaflets of leaf nine from four year old plants. Boron concentration was determined by the procedure described by Bataglia et al. (1983).

Fruit, were collected approximately 7 months after spathe opening, at intervals of approximately 30 days during the periods of January to April and August to October of 2006. Productivity was expressed by the average number of fruits harvested per plant, per year.

According to the experimental design each unit was formed by three rows of five plants. The distance between plants in the row and between rows was 7.5 $\mathrm{m}$. Experimental data was from samples collected in three central plants of the central row of each experimental unit.

Experimental data were submitted to the analysis of variance and polynomial regressions adjusted to $5 \%$ significance.

\section{Results and Discussion}

Boron contents in fertilized soils increased linearly with the applied dosages (Figure 1). The high coefficient of determination $\left(\mathrm{R}^{2}=0.95 * *\right)$ relating dosages of fertilizer and boron content in the soil indicates that hot water is an efficient boron extractor. Dosages of boron fertilizer used in the experiment described in this report resulted in a soil nutrient gradient with values considered medium ( 0.21 to $0.60 \mathrm{mg} \mathrm{dm}^{-3}$ ) when the fertilizer dosage was of 2 $\mathrm{kg} \mathrm{ha}^{-1}$ The highest fertilizer dosage resulted in a soil boron concentration of $0.9 \mathrm{mg} \mathrm{dm}^{-3}$, a high content according to Raij et al. (1997)

Boron fertilizer dosages also resulted in a linear growth of nutrient concentration in plant leaf tissues (Figure 2). The results could be related to the increased concentrations in the corresponding soil samples. Comparing the average boron content in leaves of the control treatment $\left(9 \mathrm{mg} \mathrm{kg}^{-1}\right)$ to that produced by the highest boron fertilizer dosage $\left(51 \mathrm{mg} \mathrm{kg}^{-1}\right)$ it is seen 


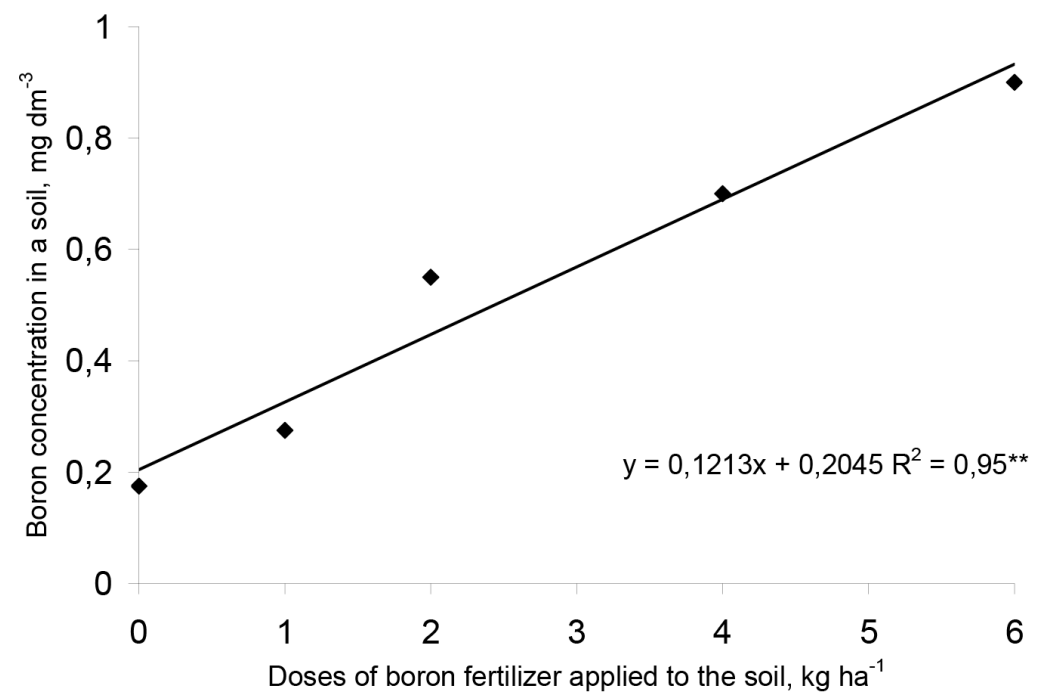

Figure 1. Boron concentration in soils of coconut palm trees cultures after application of different dosages of boron fertilizer. $* *$ Results significant at $1 \%$ level according to the $\mathrm{F}$ test.

that the treatment resulted in over a fivefold increase Only fertilizer dosages of 0,1 , and $2 \mathrm{~kg} \mathrm{ha}^{-1}$ resulted in leaf boron concentration levels lower than the considered critical level ( $\left.10 \mathrm{mg} \mathrm{kg}^{-1}\right)$ as indicated by Sobral (1998), Rogon (1984), and Manciot et al. (1980). Teixeira et al. (2003), in a study of two year old coconut palm trees of seven genotypes growing in Bebedouro, State of São Paulo, Brazil, found foliar B levels higher than $10 \mathrm{mg} \mathrm{kg}^{-1}$ (43.9 to $47.9 \mathrm{mg} \mathrm{kg}^{-1}$ of B in leaf 9).

The number of fruits per plant showed a quadratic increment with increasing boron fertilizer dosages (Figure 3).

Data in Figure 3 show that the highest fruit production resulted when the boron concentration in soil was $0.6 \mathrm{mgdm}^{-3}$ and $23.5 \mathrm{mg} \mathrm{kg}^{-1}$ in leaves. If one considers $95 \%$ of this maximum production the value would be $2,1 \mathrm{~kg} \cdot \mathrm{ha}^{-1}$, quite close to the dosage of $2 \mathrm{~kg} \mathrm{ha}^{-1}$ recommended by Teixeira et al. (2005) for soils with boron levels lower than $0,2 \mathrm{mg}$ $\mathrm{dm}^{-3}$ when the extractor is hot water.

Literature data confirm the beneficial effects of boron to coconut palm tree cultures. Santos et al. (2003) reported the positive effects of the micronutrient applied to the leaf axillae. Similar beneficial effects were also reported by Pinho et al. (2008).

It is suggested that the beneficial effects of boron are due to its role in cell wall formation and in pollen tube growth (Prado, 2008). Results shown in Figure 3 indicate that dosages higher than the one corresponding $\left(3.2 \mathrm{~kg} \mathrm{ha}^{-1}\right)$ to maximum fruit yield causes a reductions in production of up to $35 \%$ when the highest dosage $\left(6 \mathrm{~kg} \mathrm{ha}^{-1}\right)$ is used and a foliar boron level reaches $50 \mathrm{~g} \mathrm{~kg}^{-1}$. Prado (2008) points out that the interval between the boron foliar levels at maximum fruit yield and the intoxication levels is rather short. Thus, applications of boron fertilizer to coconut palm trees should be very carefully planned to avoid plant intoxication and even death. 


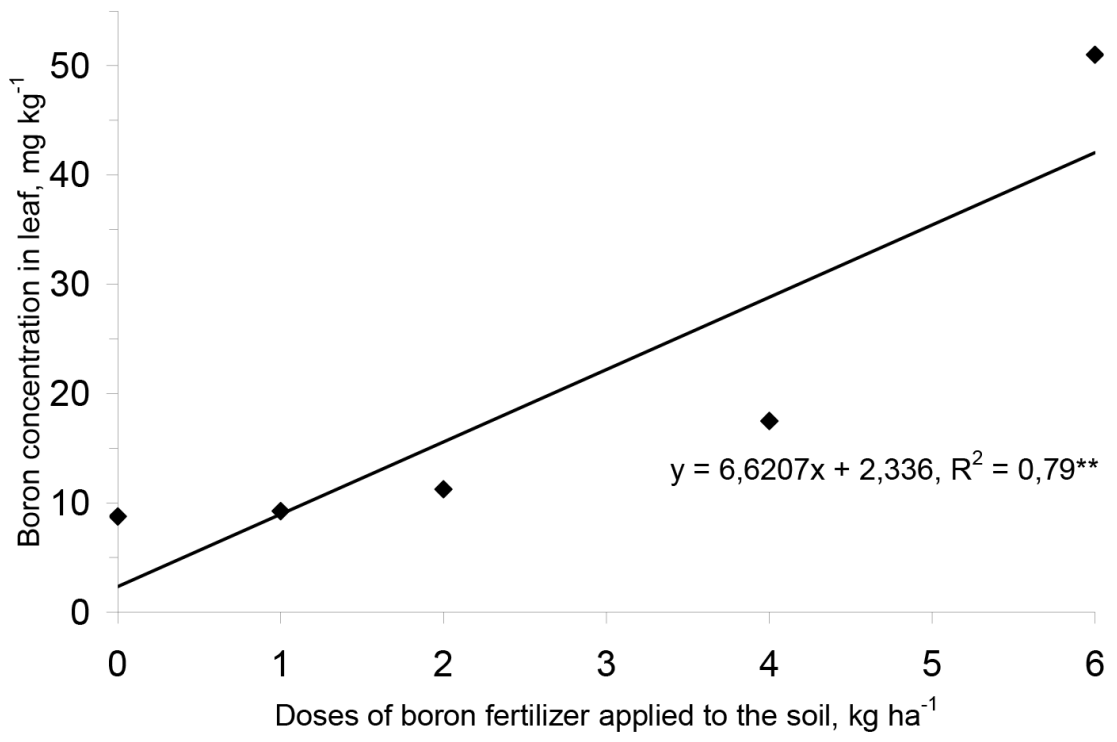

Figure 2. Boron concentration in leaf tissue of coconut palm trees determined after application of different boron fertilizer dosages to the soil. $* *$ Results significant at $1 \%$ level according to the $\mathrm{F}$ test.

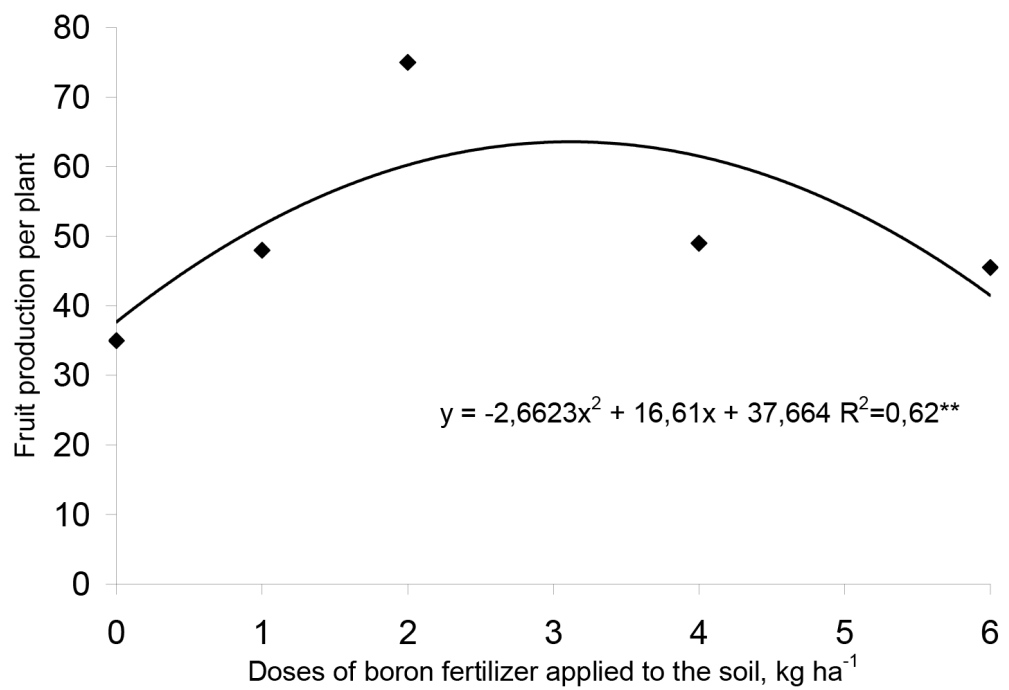

Figure 3. Fruit production of coconut palm trees resulting from the application of different dosages of boron fertilizer to the culture soil. ** Results significant at $1 \%$ level according to the $\mathrm{F}$ test 


\section{Conclusion}

The application of boron fertilizer to a coconut palm orchard increased boron soil and leaf levels and affected fruit production.

\section{References}

Bataglia, O.C., Furlani, A.M.C., Teixeira, J.P.F., Furlani, P.R.; Gallo, J.R. 1983. Métodos de análise química de plantas. Campinas. SP. Instituto Agronômico. 48p. (Boletim técnico, 100).

Broschat, T.K. 2010. Boron deficiency in palms. University of Florida, Ifas Extension, 2005. Disponível em: http://edis.ifas.ufl.edu/ep264. Acesso em 26 de jan. de 2010.

Broschat, T.K. 2011. Uptake and distribution of boron in coconut and paurotis palms. HortScience. 46, 1683 1686.

Chaudhary, D.R., Shukla, L.M. 2004. Boron adsorption and desorption in arid soils of India. Agrochimica. 48, 141-152.

Communar, G., Keren, R. 2006. Rate-limited boron transport in soils: the effect of soil texture and solution pH. Soil Science Society of America Journal. 70, 882-892.

Holanda, J.S., Oliveira, M.T., Sobrinho, E.E., Dantas, T.B. 2007. Tecnologias para produção intensiva de coco anão, EMPARN, Natal, (Boletim de Pesquisa, n. 34).

Keren, R.E, Bingham, F.T. 1985. Boron in water, soils, and plants. Advanced Soil Science. 1, 229-276.

Lima Filho, O.F., Malavolta, E. 1997. Sintomas de desordens nutricionais em estévia [Stevia rebaudiana (Bert.) Bertoni]. Scientia Agricola. 54, 53-61.
Manciot, R., Ollagnier, M., Ochs, R. Nutrition minérale et fertilization du cocotier dansle monde. Oléagineux. 35,3-55,1980.

Mattiello, E.M., Ruiz, H.A.; Silva, I.R.; Barros, N.F., Neves, J.C.L., Behling, M. 2009. Transporte de boro no solo e sua absorção por eucalipto. Revista Brasileira de Ciências do Solo. 33, 1281-1290.

Miranda, F.R., Lima, R.N., Freitas, J.A.D., Maia, A.H.N., Santana, M.G.S. 2008. Comportamento produtivo do coqueiro anão-verde irrigado na região litorânea do Ceará. In: XX Congresso Brasileiro de Fruticultura, 54th Annual Meeting of the Interamerican Society for Tropical Horticulture, 2008, Vitória.

Pinho, L.G.R., Monnerat, P.H., Pires, A.A.; Marciano, C.R., Soares, Y.J.B. 2008a. Distribuição de nutrientes e sintomas visuais de deficiência de boro em raízes de coqueiro-anão verde. Revista Brasileira de Ciências do Solo. 32, 2581-2590.

Pinho, L.G.R., Monnerat, P.H., Pires, A.A., Santos, A.L.A. 2008b. Absorção e redistribuição de boro em coqueiro-anão-verde. Pesquisa Agropecuária Brasileira. 43, 1769-1775.

Raij, B. Van., Quaggio, J.A., Cantarella, H., Abreu, C.A. 1997. Recomendações de adubação e calagem para o Estado de São Paulo. In: Raij, B. van, Cantarella. H., Quaggio, J.A., Furlani, A. M. C. Recomendações de adubação e calagem para o estado de São Paulo, Campinas, v.2, p. 1-12, (Boletim técnico, 100).

Raij, B. Van, Andrade, J.C., Cantarella, H., Quaggio, J.A. 2001. Análise química para avaliação de fertilidade do solo, Campinas, p.285.

Rognon, F.C. In: Martin-Prevel, P., Gagnard, J., Gautier, P. 1984. L'analyse végétale dans le contrôle de l'alimentation des plantes tempérées et tropicales. Tec\&Doc, Paris, p.447-57. 
Rosa, R., Lima, S.C., Assunção, W.L. 1991. Abordagem preliminar das condições climáticas de Uberlândia Sociedade \& Natureza. EDUFU, Uberlândia, p. 91108.

Santos, A.L., Monnerat, P.H., Carvalho, A.J.C. De. 2004. Estabelecimento de normas DRIS para o diagnóstico nutricional do coqueiro-anão verde na região norte fluminense. Revista Brasileira Fruticultura. 26, 330-334.

Santos, A.L., Monnerat, P.H., Alves, E.A. B.2003. Teor foliar de boro em função da aplicação de bórax na axila foliar de coqueiro-anão verde no Norte Fluminense. Pesquisa Agropecuária Desenvolvimento Sustentável. 1, 165-171.

Silva, N.M., Carvalho, L.H., Kondo, J.I.; Bataglia, O.C., Abreu, C.A. 1995. Dez anos de sucessivas adubações com boro no algodoeiro. Bragantia. 54, 177-185.

Siqueira, E.R., Ribeiro, F.L., Aragão, W.M. 1997. Melhoramento genético do coqueiro. In: Ferreira, J.M.S.; Warwick, D.R.N.; Siqueira, L.A.A Cultura do coqueiro no Brasil.(Ed.). Aracaju: EMBRAPASPI, 1997, p. 73-98.

Soares, M.R., Casagrande, J.C., Alleoni, L.R.F. 2008. Adsorção de boro em solos ácricos em função da variação do $\mathrm{pH}$. Revista Brasileira de Ciências do solo. 32, 111-120.

Sobral, F.L. 1998. Nutrição e adubação do coqueiro. In: Ferreira, J. M. S., Warwick, D. R. N. \& Siqueira, L. A. A cultura do coqueiro no Brasil. (Ed.). Aracaju: Embrapa-SPI, 1998. p.129-157.
Srinivasa Reddy, D.V., Upadhyay, A.K. Gopalasundaram, P., Hammed Khan, H. 2002. Response of high yielding coconut variety and hybrids to fertilization under rainfed and irrigated conditions. Nutrient Cycling in Agroecosystems. 62, 131-138.

Prado, R.M. 2008. Nutrição de Plantas. 1. ed. São Paulo: Editora UNESP, 2008,407 p.

Teixeira, L. A. J., Bataglia, O. C., Buzetti, S., Furlani Junior, E. 2005. Recomendação de adubação e calagem para coqueiro (Cocos nucifera L.) no Estado de São Paulo - $1^{\text {a }}$. aproximação. Revista Brasileira Fruticultura. 27, 519-520.

Teixeira, L.A.J., Silva, J.A.A. 2003. Nutrição mineral de populações e híbridos de coqueiro (Cocos nucifera L.) cultivados em Bebedouro. Revista Brasileira de Fruticultura. 25, 371374.

Viégas, I.J.M., Thomaz, M. A.A., Silva, J.F. da, Conceição, H.E.O. Da, Naiff, A.P.M. 2004. Efeito da omissão de macronutrientes e boro no crescimento, nos sintomas de deficiências nutricionais e na composição mineral de plantas de camucamuzeiro. Revista Brasileira de Fruticultura. 26, 315-319. 